\title{
Literature of the Inner Frontier: Establishing the Term
}

\author{
Alexander V. Markov* \\ Russian State University for the Humanities \\ 6 Miusskaya ploshad', Moscow, 125993, Russia
}

Received 10.01.2017, received in revised form 17.08.2017, accepted 25.08.2017

\begin{abstract}
The contemporary novel is undergoing significant changes, one of which is a new balance of social and inner experience in which a marginal condition of a person is not described from the outside, but as internal speech, as the main element of the novel. The article points to the origins of this phenomenon in the classical culture, introducing the term "literature of inner frontier" and investigates the minimum conditions allowing to attribute a text to this literature. It is proved that this literature has focused on the productive models to describe the ultimate experience as everyday life, such as the tragedy Faust by Goethe, and represents a return to the origins of the novel as lower genre. It is shown that this type of frontier narrative, despite conflicting reviews from critics, changes the today literary process, creating a whole new way to image the inner world of man.
\end{abstract}

Keywords: historical poetics of the novel, contemporary novel, contemporary literature, frontier, marginality, speech genres.

DOI: 10.17516/1997-1370-0153.

Research area: philology, theory of literature.

\section{Introduction}

The word "frontier" has two meanings: the land frontier, as a territory with a special legal status and social demands, and the state of the frontier as a contradictory psychological state of being in marginal condition with approval of the constructive possibilities from this marginal status. If the first meaning is usual under discussing choice of literary themes and preferences within the logic of the genre (say, that the best adventures are reasonable on the geographical frontier), the second meaning is rare for literary criticism. We will speak about the inner frontier novel as description of the marginal existence taken as inner problem of the main hero's mind. We aim to make this definition clearer after historical sketch of the particular phenomena of lower literature as literature of inner frontier, or to say about the psychical conditions of frontier experience.

We refer to the inner frontier novel texts of Petronius and Apuleius with much credence, where the lower state of life of the heroes is highlighted with lower genre and special relationship to philosophy: a lower affair needed to justify philosophy to non-philosophers, who see in philosophy only means to prosperity. This novel must show that every drop to the

(C) Siberian Federal University. All rights reserved

* Corresponding author E-mail address: markovius@gmail.com 
bottom, closer to the animal world; these are the passions designing the very existential position of philosophy, the opportunity to see everyday events as existential.

\section{Theoretical frame}

The novel of inner frontier is highly inspired by great epic constructions, introducing novelistic plot to express inner liminal conditions, such as Faust by Goethe. The main backstage of the inner frontier narrative is the reconceptualisation of the basic Aristotle's opposition between history and fiction. Aristotle struggled for privileged place of the poet, who dares to make fictions, and limited the historian only to write about facts. The intention of the philosopher was to rise up poetic mission as now aesthetically, not religiously motivated. But medieval thinkers tried to reintroduce religious motivations of any intellectual act, and to put creative activity on intellectual speculative grounds. So, Isidore of Seville treats the basic opposition of poetry and prose not as opposition of fiction genres and facts, but as opposition of rule to imagine facts and rule to represent facts. Stylistic of imagination was a mood of poetic licence, how to explain facts in addition to different ornaments and interpretations by means of phantasy, incorporated to the text. Stylistic of factual speech was a plain style, enough clear to demonstrate the beauty and truth of facts. So, after medieval reconceptualization of the ancient theory of genres of speech and theory of imagination as both cognitive instruments, the opposition of poetry and prose was rearranged not around genres of literature, but around styles borrowed from the stylistic spectre of ancient rhetoric. After this experience of the far from us ages the fiction became an arrangement of stylistic decisions. All elements of the inner frontier could be built now in the dominant style of the literature of the period.
The inner frontier novel now attempts to privilege the position of the poet after break of old stylistic systems. It is the way of rehabilitation of poetry parallel to rehabilitation of prose privileges in verbatim technique of speech (e.g. verbatim prose of Svetlana Alexievich). Reinvention of the frontier as cultural pattern became an important feature of the cultural selfconsciousness. Such epochs as baroque counterreformation or decadent modernism were epochs of the restoration of the old world-view, making space of the old style triumph. This triumph worked as inner frontier in art between narrative and effects, or between enargeia and decorum, if we use terms borrowed from classical rhetoric. This inner frontier puts question not about interaction of images and figures, not about interference of narrative and poetic strategies, but about permanence of images in the age of fluent and mutable realisation of any ideas.

\section{Statement of the problem}

The sense of inner frontier not to be limit of cultural identity, but to demonstrate its stability independently of personal virtues, as property of the cultural construction. If production of virtue is the main task of the culture, it is not frontier culture: this culture mobilise rationality not for inner stability, but for extensive or intensive expansion. The question on the quality of the limits and borders is completely changed with the question of strategy. The culture of inner frontier is not strategic, but ecstatic, if we understand ecstasis not as liminal condition, but as most deep and sincere form of cognitive perception, according to the theories of Heidegger and Kristeva. We can identify Plato as thinker of virtues and Plotin as thinker of inner frontier as of not-foregone experience.

The inner frontier makes us not to follow any idea as self-obvious, but to touch this idea as overcoming its own limits as own conditions 
to be seen as such. Now this idea is not mood to reconcile interests, but to have interest to unconditional. The inhabitants of the cultural frontier feel threats, but feel their own political existence as fact, but not as result of any system of political regulations. We see as the opposite principles the frontier self-organization in cultural frames and the political system of checks and balances. The first case is the case of standing for the truth, penetrating real cultural habits, and sensitivity to the own marginal position, and the second case is checking of conditions to the truth-making. So, the first case is close to the selfreflection or religious humility, and the second case is close to the self-determination or political virtue.

The main property of the inner cultural frontier is not to reinvent the order of knowledge, but the order of expression. We know some precedents from the classical times: the artificial language of ancient Uranupolis, city aimed to be frontier of hellenism between former Attic and former Macedonian world was an apotheosis of the united infrastructure of the city. We appreciate artificial idioms as kind of pedantic slang, but it was constructing of linguistic units able to reproduce the inner order of affectation, to support ecstatic feeling of speech with constructing of the motivated sense. The reason to make common language an artifact was not to replace words with observances and definitions, but to define senses according to the inner analytical experience. Inner experience is subject not of discussional demands, but of scrupulous rethinking. We see now in cryptography, cybernetics and system theory these rules of interactions not as realization of equal demands of interacting substances, but as reframing of the realized understanding. Here understanding is not design of any system of preconditions, but peculiarity of the interiorized experience.

\section{Methods}

If we want to have a great novel as novel of inner frontier, we need to exercise a list of demands, or we will have only episodes of frontier experience. In this list we include borrowed plot (or mash-up of plots), original optics, sublimation of low genres and artificial imaginary. E.g., the famous Laurus (2012) by Eugeny Vodolazkin proposes a parody of the idiolect of Russian Soviet intelligentsia as if it was part of the genuine life of Medieval Russia. This conscious anachronistic use of professional idioms, reflected as social position of contemporary thinking class, reserves for heroes the frontier, but only as time experience. The question is if time saves or destructs these idioms of everyday communication and intellectual content of social relations? But the experience of the protagonist of this novel not of the inner frontier, but of his intentional pilgrimage, his positioning himself as nomade in intellectual spaces. This eminent novel has its effects through combination of inner frontier and inner center: the language mirrors genuine central experience, and mistakes of idioms are not in the experience, but in expression as inner frontier of language. When protagonist escapes from coercion, his inner emotion is common: to combine conscious non-violence and affective seek for happiness.

The impossibility of great novel of inner frontier in contemporary Russia goes with the dominant frontier organization of the local social space. The urban planning, much decorative and theatrical, and social interactions, with unexplained rules, makes the space of the frontier as the space of spectacular self-evidence together with sophisticated communication conditions. Demonstrative behavior is the backstage aimed to underline direct character of social decisions. This social climate is best to develop inner frontier sense in poetry and short prose, as genres of realization of direct aesthetical decisions, but 
not benevolent to great prose with openness and unpredictable interactions as main features of the narrative and plot. We see the main effect of this break among short and great narrative forms in the dehistoricization of public discussions: Russian intellectuals ordinary discuss the space as a problem of cultural development, and rethink history not as field of action, but as medium of just relations and as mosaic of comparisons. If we compare different phenomena and declare results as "history", we exclude any logic of great novel.

But the novels of Russian writers who are permanent residents of the Western world are of sharpened direct style of social practices representation. This feature differs these novels from the most novels written in Russia, where social practices are given as preconditions of the expected forms of justice or achievements, but not as motivation for any stable style. Representational type of stable style demands to ascribe stylistic interest to all characters of the novel.

Now we can mention several versions of this novel. For example, Alexei Makushinsky's novel The ship to Argentina (2014) is novel about the artists in the broadest sense: each character acts as an artist in the sense that he masterfully handles things and even with more virtuosity handles words. Heroes do not aim to go through some stages of development, but tend to things that they seek, as household items, travels, destinies, to develop themselves to the greatest level to allow heroes just again talk to each other. In this novel inner frontier is achieved by the collapse of years of teaching and years of wandering, taking Goethe's term, and keeps it in the novel associations of things and events, which are recognized as familiar to heroes. We can speak on inner frontier here because the characters do not learn in the life experience or through reflection on their memories, but once identify the sense ecstatically as granted.
Another realization of the inner frontier we see in the novel by Mikhail Shishkin Maidenhair (2005) where distinction of cultural norm by heroes fully depends from their ability to inscribe themselves in the plot, not in the patterns of behavior, but in the patterns of genres. This dependence is completely non-mimetic: if usually novel takes heroes as subjugating their character to the plot, heroes of this novel have right to forget their character for the plot integrity, as inner frontier of any self-description of contemporary human. They have no mask of the plot content, but they mask themselves as main circumstances of the inner frontier of the European civilization. We see here no postmodern game and no symbolist emphatic expression, but making heroes themselves circumstances of the reader's experience. Every reader needs to reread his own destiny on the background of heroes' misreading, and it is not the privileged position of reader, but risks of misunderstanding as external form of the inner frontier. Inner frontier is self-content in its cultural presumptions and risky in its external troubles. This novel sharply criticizes conception of autonomous realization of character in Soviet literature, the author allows us to understand that if we understand our character, we couldn't understand our position in the world, and vice versa.

\section{Discussion}

Now we see in Russian emigre literature a university novel, as Vineta (2006) by Oleg Juriew. The trivial for contemporary Russian literature topic of archaeologist or geologist as protagonist of analytic work with the past here is modified as way not to real historical materiality, opposite to the inconsistency of the today Russian life, but to phantoms of the past, different from real psychological agenda of today. These phantoms are not only marked in space and time as 
important points of general historical experience, but their character is to rearrange the space of our recollections. The inner frontier novel demands apart from the reality of these phantoms in mystical scenes the real character of active life. But we failed to find the main principle of the inner frontier novel in this kind of narrative. We can't see the sequence of study years and travelling years, as sequence or two necessary parts of inner frontier formation.

The American model of university novel as Goethe-style novel in which the herolinguist studying literature in every way, in fact, becoming literary man, like Faust, who created the art of memory as a complex encrypting art of the life. In the plot, the protagonist of the novel is suddenly is protagonist the second part of Faust, alone with the very foundations of European culture and European love (as sophist Gorgias wrote about Elena as a culprit not of the war, but the literature) (Cassin, 2000). A.S. Byatt in the preface to Faust by Goethe (Byatt, 2005) defined the role of Mephistopheles as harmless crazy, probably by analogy with the "harmless joy" of classical tragedy (Rabinovich, 1991). A.S. Byatt also writes that in the Faust Goethe has contained "all ranks of its occupations and the way most of the work", in other words, immersed in himself as a scholar, to come out as an employee of the word.

The problem of the American model of inner frontier is wandering without violence of training, the mutation of culture of norms to the culture of frontier self-confidence. E.g., in the novel by J. Eugenides Middlesex (2002) conflict of Apollo and Dionysos resolved as conflict of the androgyne identity. Unlike Nietzsche's model in which Dionysus is the god of the mask, and violence over the body still applies between Apollo and Dionysus, if Apollo is king of dreams, here the violence is social convention. And in the Possession (1990) of Byatt backbone idyllic scene of the meeting, still being challenged as a legacy of romanticism as listening for other people's voices, escapist to endless fantasy masks, protracted years of teaching. While wandering, the reality appears not as Dionysian, but as multiplicity of ways of life. These are the years of wandering as the only way to collect impressions, rather than follow them (which would be violence), and are for example main topic of the novels of Donna Tartt: the hero as a detective own destiny released precisely on the finished state of violence, while any attempt to follow the statement of own life task is catastrophic.

So it is important the appearance in recent Russian literature novels in which violence is thematized, not by creating of probability model in which violence can be reduced (as in the novel M. Petrosyan The house in which ...), but by just studying of the inner frontier as part of cultural frontier. The year 2016 was rich on these so say Russian research novels. The novel Kaleidoscope by S. Kuznetsov shows only years of wandering as collection of memories and the only way not only to learn now the lessons of history, but to learn in the future to have these lessons, and before that future lessons the future would oppress the memory and not lead it. More precisely this topic is shown in the novel by A. Petrova Appendix, where the memory operates as a selforganization of the heroes, fleeing the violence, which carries with them even seemingly innocent conversations.

The novel Appendix is the change of the readers' experience as change of the system of public states of the narrative. It is usual in the novel to imply public reactions in the text, as strategy of modeling the reader's attention. The public interest could be implicitly presented with parody and indignation, but to imply it is part of construction, similar to angels going out of the frame in baroque paintings or hands gestures in Renaissance frescoes. These artistic 
gesticulations are of the same task: to guarantee the wit of the witness.

The Appendix is related here more to architecture principles, than painters' visual constructions. the audience seemed lost among the columns, but it finds itself as public, rather than mob. Another difference of Petrova's novel from the previous forms of contemporary novel is absence of any spontaneous effects, usually used to underline posing existential questions, when suddenly the situation itself compels the reader to the new feeling of his own life, but that this very sudden feeling seems to him legitimate as interesting way read the novel. In the Appendix different versions of sensuality of the characters caught up in the ultimate situation: reader, confronted with different standards of sensibility, inevitably begins to reschedule his reading in novel mode: choosing lyrical, dramatic and documental keys simultaneously.

Russian reviewers had many doubts on the ethical position of the novel. Anna Narinskaya (2016), prominent observer of the highbrow Russian newspaper Kommersant, tried to describe the narrative strategy as triumph of marginal experience, as hymn to the social bottom. Narinskaya see in this novel a kind of posttraumatic syndrome, after the trauma affecting sentimental constitution of everyday life. Decay of the sentimental life, destruction of ordinary emotional tensions leads to the productive communication with marginals as only mood to communicate. More benevolent to the novel observer Viktor Son'kin (2016), specialist in Roman history, in his commentary for the Russian book review blog gorky.media, tries to present the novel not as plot narrative, but as so called poetic prose, where shine of images and figures is the main interest. This frustration of Russian critics takes part from specific of the inner frontier novel as compared with common adventure novel or psychological novel. If the last forms are of established culture patterns of self-esteem, the novel of inner frontier is play on the scene of the proper marginality, going back to the narratives of Petronius and Apuleius, to the roman locus of the low and dirty narrative. Petrova as a resident of Rome necessary continues tradition to talk about low and miserable as area of misfortunes that overtakes us not as tragic fate, but as property of the speech to be commensurate to fatality of our existence.

In such novels as American novels of inner frontier, failure occurs from a humorous mood, which can only point to block unreasonable behavior, but cannot rule out violence. American great novel drifts from humour to laugh: e.g. Eugenides' novel is a novel about the nature of laughter on the human understanding of nature and Tartt's novels are novels about laughter speech on familiar ideas, suggestion unique experience. Russian romance rather drifting in the direction of fear, not in the sense of terror, but in terms of frustrating, lacks the right words. In the Petrova's novel words and events should not agree in their absurdity and horror and let the reader watch their life, not their laws.

Such fear is above all criticism of the usual pathetic experience as the experience of inflated expectations, of allegedly imagined natural development and implementation of the law-governed plan. Of course, we are not talking about the destruction of the absurd or the expectations, but only of a certain culture to do with plans and designs. In a recent text by Linor Goralik Operetta about the sick of many (2016, published in Vozdukh: zhurnal poesii, 3-4), or of a single which can be called a poetic summary of the future perfect of inner frontier novel, just described as prophesy, righteousness, poetic madness, which we used to put in the center of what is happening; Madmen Chamber turns Apostolic Assembly, in which the most painful of all, Thomas, has to break the silence. 
Vigil, in other words a repetition of the events of sacred history, is the history in which the singing anesthesia, bound all, Scripture reading this is just a blow to the eloquence: eloquence tearing character, is intolerable, and only flesh has some constant tone, "countertenor whistling". Singing studies, but the flesh is already recognized its years of wandering.

The flesh can turn the language only in a broken, half-dead language that can no longer say anything, he is constantly in search of their own moments of existence, while the flesh says, "and I keep quiet, and I keep quiet, keep quiet and I you". Then it develops novel situation in which the character, which is reality itself declares no man, but only a moment of pain, gaping wound, turning the situation, says the litany, as proceeds from the night service to the liturgical situation, aware of its situation as a sacrifice. Vigil "panic treats Latin", in other words, the panic declares itself the language rather than the frontier. Of the inner frontier is the final song, the antiphon. The upper voice sings referring to the meaning, "Say something simple", and the bottom picks up the voice of rhyme speaks of maintaining the body "in the bosom of boring rest-of-I" - the sound, pulling out of the tube under the action of the vortex of fame, demanding to speak something simple, swirl, which should hang the entire situation settles down in pure tone variability, beating "boring" rest. There are two voices do not find out the relationship, but argue that the only turn of events may be purely ecstatic.

\section{Conclusion}

So the inner frontier novel shows that "normal conversation", "normal science" or "normal statement" is actually quite conventional etiquette, built on mutual violence: people think that they are free to draw conclusions, but in they actually take their own conclusions inexorability inexorable ancient fate. While true freedom is achieved precisely when you cannot deal with his words as with stranger, and watch as the word has gone through the violence to ourselves to become a cover, saving others from violence.

The concept of inner frontier novel allows to specify many familiar concepts. It is not familiar to us novel of growth and maturation of the hero, what would be a novel built on conventional physics, where the hero is a mask of fate, eventually winning destiny, but it is a novel of such a collision of principles, in which the hero's speech is fundamental and fixed while hero deeds tear himself as suffering required. The speech here is not constructive for practical reasons, but enough affective to save protagonist from everlasting suffering through not-appropriative character.

\section{References}

Byatt A. (2005). Preface, Johann Wolfgang von Goethe, Faust, Penguin Books, VII-XX.

Cassin, B. (2000). Voir Hélène en toute femme, D'Homère à Lacan, Paris, Institut SanofiSynthélabo.

Narinskaja A. (2016). Rim vnutri [Rome inside]. In Kommersant 18.11.2016. Available at: http:// www.kommersant.ru/doc/3137729

Rabinovich E.G. (1991). "Bezvrednaja radost"”: O tragicheskom katarsise u Aristotelja [A harmless joy: on tragic catharsis of Aristotle]. In Mathesis. Iz istorii antichnoj nauki i filosofii [Mathesis: from the history of ancient science and philosophy]. Moscow, 103-113.

Son'kin V. (2016). Slavnogo grada zhitel' [A resident of glorious city]. In Gorky. media 20.09.2016. Available at: https:/gorky.media/reviews/slavnogo-grada-zhitel/ 


\title{
Литература внутреннего фронтира: \\ обоснование термина
}

\author{
А.В. Марков \\ Российский государственный \\ гуманитарный университет \\ Россия, 125993, Москва, Миусская площадь, 6
}

\begin{abstract}
Современный роман претерпевает значительные изменения, одно из которых - новое отнотение соииального и внутреннего опыта, при котором маргинальное состояние человека не описывается извне, но находит свою речь. В статье указано на истоки такого явления в классической культуре, введен термин «литература внутреннего фронтира» и исследовань минимальные условия, позволяющие отнести произведение к данной литературе. Доказано, что эта литература ориентирована на продуктивные модели описания предельного опыта как бытового, как трагедия «Фауст» Гёте, и представляет собой возвращение к истокам романа как низового жанра. Показано, что данные произведения, несмотря на противоречивые отзывы критиков, изменяют современный литературный проиесс, создавая совершенно новый способ изображения внутреннего мира человека.
\end{abstract}

Ключевые слова: историческая поэтика романа, современный роман, современная литература, фронтир, маргинальность, речевые жанры.

Научная специальность: 10.00.00 - филологические науки, 10.01.08 - теория литературы. 